\title{
Lacrimal Gland Mucoepidermoid
} Carcinoma

National Cancer Institute

\section{Source}

National Cancer Institute. Lacrimal Gland Mucoepidermoid Carcinoma. NCI Thesaurus.

Code C6091.

An extremely rare carcinoma that arises from the lacrimal gland. It is characterized by the presence of infiltrating nests of epidermoid cells and mucus producing cells. 